\title{
Education of Household Members and Nutritional Status of Children in Bangladesh Halima Akhter ${ }^{1}$ and M. Ershadul Haque ${ }^{2 *}$ \\ ${ }^{1}$ Department of Business Studies, University of Information Technology \& Sciences, Dhaka-1212, Bangladesh \\ ${ }^{2}$ Department of Statistics, Dhaka University, Dhaka-1000, Bangladesh
}

( Received: 30 March 2017 ; Accepted :17 December 2017)

\begin{abstract}
Malnutrition is the burning question all over the world's public health. Bangladesh is one of those countries where level of malnutrition of infant and child is very serious and many problems that results from malnutrition in Bangladesh. The aim of this study is to substantiate whether there exists any influence of parents' education for child nutrition as well as to find out the potential effects of non-parental household member's literacy level on child malnutrition. In this study we have found that parents' education is an important factor for child nutrition. Also other household members' education has significant impact on stunting (height for age) and underweight (weight for age). The results of this study focus the policies that encourage participation in schools and higher education program as well as improve economic condition of the households to dilute child malnutrition in Bangladesh.
\end{abstract}

Keywords: Anthropometric status, stunting, wasting, underweight, BDHS, multinomial logistic regression model.

\section{Introduction}

There is an enduring worldwide effort focused on the complete eradication of tremendous poverty and hunger. Ninety percent of the worlds stunted children live in 36 developing countries ${ }^{1}$. Malnutrition remains a major cause of disability and mortality, ranked as the top cause of global burden of disease and underlying $53 \%$ of deaths in children under five years ${ }^{1}$. The pessimistic scenario suggests that child malnourishment will increase from 166 to 175 million children by $2020^{2}$. The high levels of malnourishment in children and women in South Asia and Sub-Saharan Africa pose a major challenge for child survival and growth. The examples of Thailand, Vietnam and China show that the problem of malnourishment is entirely preventable.

Malnutrition among children have lifelong implications, its outcomes not only cover the whole life but are transferred from one generation to another. The highest prevalence of malnutrition in Bangladesh among the world has been observed. Among the Bangladeshi children aged below 5 years $41 \%$ are stunted, $16 \%$ are wasted, and $36 \%$ are underweight ${ }^{3}$.

All over the developing world education is considered as the key factor for minimizing malnutrition. In these countries, it is well established that mothers' education has much more influence on child nutrition than other members of the family. It has been argued that mothers' education has greater influence than fathers' education on child nutrition as fathers tend to work outside the home and children's have more time to mothers ${ }^{4}$. If mothers are unable to give quality time to their child, in that case other household members education may be effective for childcare ${ }^{5}$. A study conducted in Vietnam using two nationally representative surveys reveals that there exist no significant association between maternal education and child nutrition. Probably since women have to involve work simultaneously at home and outside, they do not get sufficient time to give for breastfeeding as well childcare ${ }^{6}$.

It is less explored that child nutrition is affected by neighbors', friends of mothers. In three studies Kravdal ${ }^{7-9}$ claimed that since uneducated people in the community may be benefited in all the sector of health issue from their higher educated neighbors' in that community so mortality rate may be reduced by the educational growth in the community. These sights are also similar withothers ${ }^{10-12}$. If job holder mother could not able to give proper time to childcare in that case other household members such as grandparents, older siblings who are more educated than the mother may play effective role in childcare ${ }^{13,14,4,5,15}$. A very few research suggests others household members education may play vital role for child nutrition ${ }^{9-12}$ although there are large number of study which found association between child nutrition and parents education.

In this study, we have given emphasis to highlight the relative importance of others household members education level at the side of the parents education level on child nutrition which will be helpful for policy maker to improve the existing situation of child malnutrition in Bangladesh by utilizing the Bangladesh Demographic Health Survey data. The education level of household member other than parents is considered as the maximum level of education of a member of that family having most education besides parents.

\section{Data, Measures and Methods}

The data used in this study is collected from the BDHS, 2011. Bangladesh Demographic and Health Survey is a nationwide representative survey where the data is collected from two-stage stratified sampling procedure. In the first stage, a total of 600 clusters is selected, 393 clusters from rural and 207 clusters from urban areas. An average of 30 households are selected using systematic sampling from each enumeration area in the second stage. Finally 17842 ever married women of age 12-49 years from the selected households is interviewed to collect data on a complete history of their live births, sex of children including month and year of each birth, survival status and age at the time of the survey or age at death along with socioeconomic and demographic variables.

This study focuses on the 6555 children aged 0-59 months for which complete and plausible anthropometric data as well as data on other socioeconomic and demographic measure were collected.

\footnotetext{
* Author for correspondence. e-mail: ershad_sbi@du.ac.bd
} 
In this study outcome variables are height for age called stunting, weight for height called wasting and weight for age called underweight where all are measured as indicators of nutritional status of children although it is very difficult to determine the nutritional state of children using a single measure. Stunting is a measure of chronic malnutrition that indicates reduced linear growth (height) compared to the expected growth in a child of same age. Wasting indicates short term changes in nutritional status. It means a deficit in body weight for same height. And underweight indicates a deficit in body weight compared to the expected weight for the same age, which may result either from a failure in growth or loss of body weight due to malnutrition. For a given group of children, Z-score method is recommended in order to have a comprehensive understanding of malnutrition. In case of stunting it will be considered as severely stunted if $\mathrm{HAZ} \leq-3 \mathrm{SD}$, moderately stunted if $3 \mathrm{SD}<\mathrm{HAZ} \leq-2 \mathrm{SD}$. For underweight it will be considered as severely underweight if WAZ $\leq-3 \mathrm{SD}$, moderately underweight if $3 \mathrm{SD}<\mathrm{WAZ} \leq-2 \mathrm{SD}$ and similarly severely wasting if $\mathrm{WHZ} \leq-3 \mathrm{SD}$, moderately wasting if $3 \mathrm{SD}<\mathrm{WHZ}$ $\leq-2 \mathrm{SD}^{3}$.

From BDHS data the independent variable others education was computed using household member recode file and merging it to children's recode file. This allowed us to create others education variables in the kids file.

All the independent variables (exposure variables, socioeconomic variables and demographic variables) used in this study are categorical having at least two categories. Exposure variables of this study are Mother's education level (no education, primary, secondary and higher), Father's education level(no education, primary, secondary and higher) and other's education (no education, primary, secondary and higher). Socioeconomic variable are wealth index (poorest, poorer, middle, richer and richest), reading newspaper (yes, no), listening radio (yes, no), watching TV (yes, no), whether household members smoke inside household (yes, no). Demographic variables are region (seven division), type of place of residence (rural, urban), sex of household head (male, female), sex of children (male, female),mother's age at birth $(<20,20-30,30+$ years $)$, birth order $(1-2,3-4,5+)$.

Three major steps have been performed for analysis in this study. At first univariate analysis was performed in order to find out the frequencies, percent distributions of each variable. Bivariate analysis was performed in order to find out the association between two variables. For this purpose chi-square test of independence is performed to test the null hypothesis that there is no association among the categories of two qualitative variables.

All three outcome variables have 3 categories each. In multivariate analysis multinomial logistic regression model was used in order to find out net effect of independent variables on each outcome variable. This model was fitted as outcome variable is categorical and having more than 2 categories. Each of the categories of response variables has coded as 0,1 , \& 2 for not stunting/wasting/underweight, moderately stunting/wasting/underweight \& severely stunting/wasting/underweight respectively. In this case two logit functions: one for $Y=1$ versus $Y=0$ and other for $Y=2$ versus $Y=0$ can be constructed. Let $X^{\prime}=$ $\left(x_{0}, x_{1}, x_{2}, \ldots, x_{p}\right)$ denote the vector of $p$ covariates along with the constant term $x_{0}=1$ and $\beta_{i}^{\prime}=\left(\beta_{i 0}, \beta_{i 1}, \beta_{i 2}, \ldots, \beta_{i p}\right)$ be the vector of $(p+1)$ parameters for $i^{t h}$ category of the response variable with $\beta_{0}$ is a null vector. The conditional probability of the outcome categories are $P(Y=i \mid \mathrm{X})=$ $\frac{\exp \left(\sum_{j=0}^{p} \beta_{i j} x_{j}\right)}{\sum_{m=0}^{2}\left(\exp \left(\sum_{j=0}^{p} \beta_{m j} x_{j}\right)\right)} ; i=0,1,2$. Then the logit functions are $g_{l}(X)=\ln \left(\frac{P(Y=l \mid X)}{P(Y=0 \mid X)}\right)=\sum_{j=0}^{p} \beta_{l j} x_{j} ;$ and the odds of outcomes $Y=l$ versus $Y=0$ for a given $X$ is $\exp \left(\sum_{j=0}^{p} \beta_{l j} x_{j}\right) ; l=1,2$. Consider two group with covariate as $X=U \& X=V$ then the odd ratio becomes $O R_{l}=\frac{\exp \left(\sum_{j=0}^{p} \beta_{l j} u_{j}\right)}{\exp \left(\sum_{j=0}^{p} \beta_{l j} v_{j}\right)} ; l=1,2$. The subscript of the odds ratio indicates which outcome is being compared with outcome $Y=0$. Odds ratio is greater than 1 indicates the odds of outcome category has increased; less than 1 indicates the odds has decreased ${ }^{16}$.

To analyze the data, the package STATA 12.1 has been used and data are adjusted for sampling design including the sampling weights. In the analysis, sampling design adopted by BDHS, 2011 is considered, where enumeration area is primary sampling unit and urban city corporation, urban other than City Corporation and rural in each division are considered as strata.

\section{Results}

In order to know the pattern of distribution of the observation in different groups percentage distributions of different variables are computed which is helpful for further analysis. From the univariate analysis of outcome variables we have found that among 6555 children age 0-59 month 24.87 percent are moderately stunting and 14.42 percent are severely stunting where 12.11 percent are moderately wasting and 4.04 percent are severely wasting. These percentages for moderately and severely underweighted child are 25.11 and 9.72 respectively.

From the analysis of other $\mathrm{HH}$ member literacy we found that $23.45 \%$ have no education, $35.56 \%$ have primary education, $28.02 \%$ have secondary education and $12.97 \%$ have higher education. Among 6555 children 51.61\% are male and $48.39 \%$ are female. Most of the people not read newspaper and listen radio regularly but most of them watch TV regularly. Average age of children is 28 month and average proportion of children is 0.23 .

From the bivariate analysis results in table-1, the study found that the prevalence of stunting of children is highest among the children whose mothers have no education. Stunting level is decreasing with the increase of mother's education level(p-value $<0.001)$. Prevalence of stunting is highest for those children whose other $\mathrm{HH}$ member has primary education and lowest for the children having other 
$\mathrm{HH}$ member has higher education. Prevalence of stunting is decreasing with the increase of education level of them (pvalue $<0.001)$. Stunting is associated with region(pvalue $<0.05)$, place of residence ( $p$-value $<0.01)$, wealth index (p-value $<0.001)$, mother's age at birth ( $p$-value $<0.05)$, birth order ( $p$-value $<0.001)$, reading newspaper ( $p$-value $<0.001)$, watching TV (p-value<0.001), and $\mathrm{HH}$ members smoke inside HH (p-value<0.001).

Prevalence of wasting of children is highest among the children whose mothers have no education. Wasting level is decreasing with the increase of mother's education level(pvalue $<0.001)$. Wasting is highest among the children whose fathers' have no education, lowest among the children whose fathers have higher level education. Father's education has significant ( $p$-value $<0.01$ ) association with wasting status of children. Wasting status is highest for those children whose other $\mathrm{HH}$ member has primary education. And wasting status is lower with the increase of education level of them( $p$-value $<0.01)$. Wasting is associated with place of residence $(p$-value $<0.01)$, wealth index $(p-v a l u e<0.01)$, mother's age at birth (p-value $<0.05)$, birth order ( $\mathrm{p}$ value $<0.05)$, reading newspaper $(\mathrm{p}$-value $<0.10)$, watching TV (p-value $<0.001)$ and $\mathrm{HH}$ members smoke inside $\mathrm{HH}$ (pvalue $<0.01)$.

Underweight of children is highest among the children whose mothers have no education. The prevalence of underweight is decreasing with the increase of mother's education level ( $p$-value $<0.001)$. Father's education of children also has significant (p-value $<0.001)$ association with underweight of children. Underweight status is highest for those children whose other $\mathrm{HH}$ member has primary education. Underweight status is decreasing with the increase of education level of them ( $\mathrm{p}$-value<0.001). Underweight is associated with region ( $p$-value $<.01$ ), place of residence ( $\mathrm{p}$-value $<0.001$ ), wealth index ( $\mathrm{p}$-value $<0.001)$, sex of $\mathrm{HH}$ head ( $\mathrm{p}$-value<0.10), sex of children ( $\mathrm{p}$ value $<0.01$ ), mother's age at birth ( $p$-value $<0.001)$, birth order ( $\mathrm{p}$-value $<0.001)$, reading newspaper ( $\mathrm{p}$-value $<0.001)$, listening radio $(\mathrm{p}$-value $<0.10)$, watching $\mathrm{TV}(\mathrm{p}$-value $<0.001)$ and household members smoke inside household(pvalue<0.001).

\section{Multivariate Analysis}

To identify the influence of other $\mathrm{HH}$ member education along with parents' education on the nutrition status, we examine the net effect of exposure variables on stunting, wasting and underweight in model- 1 , model- 2 and model- 3 respectively after controlling some socioeconomic and demographic characteristics. Before fitting these model a model for each dependent variable was fitted considering only education of $\mathrm{HH}$ (mother's education, father's education and other's education), the exposure variables, as covariates (not shown in table for page limitation) and all these variables found to have significant influence on stunting, wasting and underweight. When socioeconomic and demographic variables were introduced in the model the significant advantage decreases (p-value increases) while remaining some sort of significant influence on child malnutrition indicating that the education of $\mathrm{HH}$ play a vital role on each dependent variable. The results of all three full model are given in the table-2, reveals the followings:

From the first model we found that mother's education has an insignificant influence on child stunting. Father's education and other $\mathrm{HH}$ member education has significant influence on child wasting. The odds of moderately stunting of the children whose father's has secondary and higher education are 0.83 ( $\mathrm{p}$-value $<0.10)$ and $0.72(\mathrm{p}$-vale<0.05) times of those whose father's has no education, whose other $\mathrm{HH}$ members hashigher education is 0.62 (p-value<0.01) times of those whose other HH members have no education, who are from middle and richest household are 0.83 (pvalue $<0.10)$ and 0.66 ( $\mathrm{p}$-value $<0.01)$ times of those who are poorest, whose mothers' age at the time of birth is more than 30 years is 0.74 ( $\mathrm{p}$-value<0.05) times of those whose mothers' age at birth is less than 20 years, whose birth order is five or more is 38 percent more ( $\mathrm{p}$-value $<0.05$ ) than those with birth order 1-2.The odds of severely stunting of the children whose father's has higher education is $0.51(p-$ value $<0.01$ ) times of those whose father's has no education, whose other $\mathrm{HH}$ members has secondary education is 0.75 (p-value $<0.10)$ times of those whose other $\mathrm{HH}$ members have no education, those who are from Chittagong, Dhaka, Khulna, Rajshahi and Rangpur are 0.77 (p-value<0.10), 0.74 (p-value<0.10), 0.52 (p-value<0.001), 0.36 (p-value<0.001) and 0.70 ( $\mathrm{p}$-value $<0.01)$ times of those from Barisal, those who are from rural is 0.71 ( $\mathrm{p}$-value $<0.01$ ) times of those are from urban, who are from poorer, middle, richer and richest household are 0.74 (p-value<0.05), 0.68 (p-value<0.05), 0.58 (p-value $<0.01$ ) and 0.35 (p-value $<0.001)$ times of those who are poorest, who are female is 18 percent more $(\mathrm{p}<0.10)$ than male children, whose mothers' age at the time of birth are 20-30 years and more than 30 years are 0.71 (pvalue $<0.01)$ and 0.74 (p-value $<0.10)$ times of those whose mothers' age at birth is less than 20 years, whose birth order is five or more is 62 percent more ( $\mathrm{p}$-value $<0.05$ ) than those with birth order 1-2, those whose mothers' read newspaper is 0.75 ( $p$-value $<0.10$ ) times of whose mothers' do not, whose $\mathrm{HH}$ members are smoke inside $\mathrm{HH}$ is 17 percent more (p-value $<0.10)$ than those are do not.

From the second model we found that fathers' education has an insignificant influence on child wasting. Mother's education and other $\mathrm{HH}$ member education has significant influence on child wasting. The odds of moderately wasting of the children whose mother's has secondary and higher education are $0.72(\mathrm{p}$-value $<0.05)$ and $0.62(\mathrm{p}$-vale $<0.10)$ times of those whose mother's has no education, whose other $\mathrm{HH}$ members has primary and higher education are 0.77 (p-value $<0.05$ ) and 0.71 (p-vale<0.10) times of those whose other $\mathrm{HH}$ members have no education, whose mothers' watching TV is 0.76 (p-value $<0.01$ ) times of those whose mothers' do not watch TV, whose $\mathrm{HH}$ members are smoke inside household is 17 percent more ( $p$-value $<0.05$ ) than those whose $\mathrm{HH}$ members are not smoke inside household. The odds of severely wasting of the children those who are from Rajshahi division is 2.02 ( $\mathrm{p}$-value $<0.10$ ) times of those from Barisal division. 
From the third model we found that fathers' education, mother's education and other $\mathrm{HH}$ member education has significant influence on child underweight. The odds of moderately underweight of the children whose mother's has primary, secondary and higher education are 0.82 (pvalue $<0.05), 0.68(\mathrm{p}$-value $<0.01)$ and 0.57 (p-vale<0.05) times of those whose mother's has no education, whose other $\mathrm{HH}$ members has higher education is 0.70 (pvalue $<0.05$ ) times of those whose other $\mathrm{HH}$ members have no education, those who are from Khulna, Rajshahi and Rangpur are 0.73 (p-value <0.05), 0.77 (p-value< $<0.01$ ), 0.70 ( $\mathrm{p}$-value $<0.01$ ) times of those from Barisal, whose mothers' age at the time of birth is 20-30 years and more than 30 years are $0.82(p$-value $<0.05)$ and $0.76(p$-value<0.05) times of those whose mothers' age at birth is less than 20 years.

The odds of severely underweighted of the children whose father's has higher education is 0.52 ( $p$-value $<0.05)$ times of those whose father's has no education, those who are from Khulna, Rangpur and Sylhet are 0.64 (p-value<0.05), 0.74 (p-value $<0.10$ ) and 1.60 (p-value $<0.01)$ times of those from Barisal, who are from poorer, richer and richest household are 0.77 (p-value<0.10), 0.47 (p-value $<0.001)$ and 0.35 (pvalue $<0.001)$ times of those who are poorest, who are female is 34 percent more $(\mathrm{p}<0.001)$ than male children, whose mothers' age at the time of birth are 20-30 years is 0.64 (pvalue $<0.001$ ) times of those whose mothers' age at birth is less than 20 years, whose birth order is five or more is 77 percent more ( $p$-value $<0.05)$ than those with birth order $1-2$, those whose mothers' watching TV is 0.79 (p-value $<0.10)$ times of whose mothers' do not.

\section{Conclusion}

The main concern of this study was to investigate the influence of different socio-economic and demographic variables on child nutrition in Bangladesh giving most important concentration to the influence of non-parent household members' education.

In this study, we found a high prevalence of malnourishment of children whose household members' education including parents' education level were low compared to children with household members' and parents' education level were high.

We provide empirical evidence that attending at least secondary level of education is essential for mothers in order to develop their children's short-run anthropometric status. The odds of moderately wasting of the children were $38 \%$ less whose mother's had higher level of education than those whose mothers' had no education. Other studies in developing countries on this topic ${ }^{17-21}$ found that mother's primary level education is elementary to improve long-run and short-run anthropometric status of child. But our study only support the previous study finding for short-run anthropometric status (wasting). This is because, this study joins a very few set of studies which have observed household's education away from education of parents'. From the previous studies we can say other's household members drop out from the education may be difficult for that family sinceother's household members' education may have fundamental effect on children's anthropometric status especially if their parents work outside the home.

For the outcome variables stunting and underweight, father's education level has a highly significant effect. We found that in order to improve children's long-run anthropometric status it is essential for their father to complete at least secondary level of education. This may be the case because Bangladesh is a male dominating country and household purchasing decisions for wellbeing is mostly depends on male decisions.

We also included an additional variable indicating other household member's education level beyond parent's education level to verify whether their education level provide any contribution to child nutrition. In line with other works $^{21-23}$ our study reveals that this covariate contributes to elucidate all three anthropometric statuses: stunting, wasting and underweight well. We have some concerns because mothers or parents are not only caretaker for children.

Mother's age at birth, birth order, wealth index, exposure to newspapers, radio and television, and household member's smoking habit inside household are also the most important contributing factor for the child nutrition. Thus the result of this study reveals the fact that stunting, wasting and underweight are the decisive measurement of child malnutrition and are affected by various exposure, socioeconomic, demographic characteristics. It is found that educated household members including parentsmakes a rising contribution to the betterment of children nutritional status.

Table 1. Percentage distribution of different anthropometric indices (stunting, wasting and underweight) by socioeconomic and demographic covariates.

\begin{tabular}{|c|c|c|c|c|c|c|}
\hline \multirow[t]{2}{*}{ Characteristics } & \multicolumn{2}{|l|}{ Stunting } & \multicolumn{2}{|l|}{ Wasting } & \multicolumn{2}{|l|}{ Underweight } \\
\hline & $\begin{array}{l}\text { Moderately } \\
\text { stunting }\end{array}$ & $\begin{array}{l}\begin{array}{l}\text { Severely } \\
\text { stunting }\end{array} \\
\end{array}$ & $\begin{array}{l}\text { Moderately } \\
\text { wasting }\end{array}$ & $\begin{array}{l}\begin{array}{l}\text { Severely } \\
\text { wasting }\end{array} \\
\end{array}$ & $\begin{array}{l}\text { Moderately } \\
\text { underweight }\end{array}$ & $\begin{array}{l}\text { Severely } \\
\text { underweight }\end{array}$ \\
\hline Mother's education & \multicolumn{2}{|c|}{ p-value $<0.001$} & \multicolumn{2}{|c|}{ p-value $<0.001$} & \multicolumn{2}{|c|}{ p-value $<0.001$} \\
\hline No education & 29.03 & 20.87 & 13.82 & 5.130 & 34.67 & 14.32 \\
\hline Primary education & 28.60 & 16.45 & 15.09 & 4.690 & 27.60 & 13.37 \\
\hline Secondary education & 23.98 & 10.85 & 10.16 & 3.440 & 21.22 & 6.800 \\
\hline Higher education & 15.53 & 6.200 & 7.330 & 3.050 & 13.08 & 3.490 \\
\hline Father's education & \multicolumn{2}{|c|}{ p-value $<0.001$} & \multicolumn{2}{|c|}{ p-value< 0.01} & \multicolumn{2}{|c|}{ p-value $<0.001$} \\
\hline No education & 29.56 & 18.20 & 13.06 & 5.070 & 31.59 & 13.39 \\
\hline Primary education & 28.17 & 16.94 & 13.54 & 4.380 & 26.03 & 12.53 \\
\hline Secondary education & 22.89 & 11.13 & 11.51 & 3.370 & 22.02 & 7.070 \\
\hline Higher education & 18.11 & 5.450 & 8.320 & 3.050 & 15.68 & 3.250 \\
\hline Other's education & \multicolumn{2}{|c|}{ p-value $<0.001$} & \multicolumn{2}{|c|}{ p-value $<0.01$} & \multicolumn{2}{|c|}{ p-value $<0.001$} \\
\hline
\end{tabular}




\begin{tabular}{|c|c|c|c|c|c|c|}
\hline $\begin{array}{l}\text { No education } \\
\text { Primary education } \\
\text { Secondary education } \\
\text { Higher education }\end{array}$ & $\begin{array}{l}27.14 \\
29.01 \\
24.58 \\
15.21\end{array}$ & $\begin{array}{l}16.13 \\
16.95 \\
11.16 \\
7.850\end{array}$ & $\begin{array}{l}14.61 \\
11.60 \\
12.44 \\
7.780\end{array}$ & $\begin{array}{l}3.930 \\
4.200 \\
4.110 \\
4.170\end{array}$ & $\begin{array}{l}28.46 \\
28.00 \\
22.43 \\
15.22\end{array}$ & $\begin{array}{l}11.14 \\
12.24 \\
8.340 \\
4.240\end{array}$ \\
\hline Region & \multicolumn{2}{|c|}{ p-value $<0.001$} & \multicolumn{2}{|c|}{ p-value $=0.3574$} & \multicolumn{2}{|c|}{ p-value $<0.01$} \\
\hline $\begin{array}{l}\text { Barisal } \\
\text { Chittagong } \\
\text { Dhaka } \\
\text { Khulna } \\
\text { Rajshahi } \\
\text { Rangpur } \\
\text { Sylhet }\end{array}$ & $\begin{array}{l}24.64 \\
24.47 \\
27.63 \\
23.07 \\
24.60 \\
26.43 \\
26.14\end{array}$ & $\begin{array}{l}19.38 \\
14.36 \\
14.31 \\
10.47 \\
8.650 \\
15.99 \\
20.33\end{array}$ & $\begin{array}{l}12.42 \\
12.27 \\
12.49 \\
11.27 \\
11.44 \\
10.49 \\
14.89\end{array}$ & $\begin{array}{l}2.950 \\
4.090 \\
4.050 \\
3.440 \\
5.770 \\
3.080 \\
4.820\end{array}$ & $\begin{array}{l}28.57 \\
25.70 \\
24.55 \\
21.74 \\
24.14 \\
25.15 \\
29.15\end{array}$ & $\begin{array}{l}10.39 \\
9.610 \\
10.17 \\
6.340 \\
10.57 \\
9.240 \\
14.89\end{array}$ \\
\hline Place of residence & \multicolumn{2}{|c|}{ p-value $<0.01$} & \multicolumn{2}{|c|}{ p-value $=0.1033$} & \multicolumn{2}{|c|}{ p-value $<0.001$} \\
\hline $\begin{array}{l}\text { Urban } \\
\text { Rural }\end{array}$ & $\begin{array}{l}23.17 \\
26.46\end{array}$ & $\begin{array}{l}12.48 \\
14.56\end{array}$ & $\begin{array}{l}10.73 \\
12.54\end{array}$ & $\begin{array}{l}3.480 \\
4.300\end{array}$ & $\begin{array}{l}20.08 \\
26.57\end{array}$ & $\begin{array}{l}7.330 \\
10.74\end{array}$ \\
\hline Sex of HH head & \multicolumn{2}{|c|}{ p-value $=0.7991$} & \multicolumn{2}{|c|}{ p-value $=0.8080$} & \multicolumn{2}{|c|}{ p-value $<0.10$} \\
\hline $\begin{array}{l}\text { Male } \\
\text { Female }\end{array}$ & $\begin{array}{l}25.77 \\
24.79\end{array}$ & $\begin{array}{l}14.14 \\
13.35\end{array}$ & $\begin{array}{l}12.21 \\
11.01\end{array}$ & $\begin{array}{l}4.090 \\
4.320\end{array}$ & $\begin{array}{l}24.94 \\
26.60\end{array}$ & $\begin{array}{l}10.11 \\
7.970\end{array}$ \\
\hline Wealth index & \multicolumn{2}{|c|}{ p-value $<0.001$} & \multicolumn{2}{|c|}{ p-value $<0.01$} & \multicolumn{2}{|c|}{ p-value $<0.001$} \\
\hline $\begin{array}{l}\text { Poorest } \\
\text { Poorer } \\
\text { Middle } \\
\text { Richer } \\
\text { Richest }\end{array}$ & $\begin{array}{l}29.65 \\
28.18 \\
25.74 \\
24.52 \\
19.42\end{array}$ & $\begin{array}{l}21.92 \\
15.95 \\
13.26 \\
11.04 \\
6.750\end{array}$ & $\begin{array}{l}14.02 \\
13.02 \\
13.86 \\
10.45 \\
8.760\end{array}$ & $\begin{array}{l}5.110 \\
4.280 \\
4.010 \\
3.180 \\
3.800\end{array}$ & $\begin{array}{l}33.20 \\
29.40 \\
24.00 \\
20.20 \\
16.89\end{array}$ & $\begin{array}{l}15.81 \\
11.84 \\
10.69 \\
6.330 \\
3.900\end{array}$ \\
\hline Sex of children & \multicolumn{2}{|c|}{$p$-value $=0.1679$} & \multicolumn{2}{|c|}{ p-value $=0.6853$} & \multicolumn{2}{|c|}{ p-value $<0.01$} \\
\hline $\begin{array}{l}\text { Male } \\
\text { Female }\end{array}$ & $\begin{array}{l}25.84 \\
25.54\end{array}$ & $\begin{array}{l}13.17 \\
15.05\end{array}$ & $\begin{array}{l}12.26 \\
11.97\end{array}$ & $\begin{array}{l}4.300 \\
3.900\end{array}$ & $\begin{array}{l}24.08 \\
26.12\end{array}$ & $\begin{array}{l}8.990 \\
10.97\end{array}$ \\
\hline Mother's age at & \multicolumn{2}{|c|}{ p-value $<0.05$} & \multicolumn{2}{|c|}{ p-value $<0.05$} & \multicolumn{2}{|c|}{ p-value $<0.001$} \\
\hline $\begin{array}{l}<20 \text { years } \\
20-30 \text { years } \\
\text { More then } 30 \text { years }\end{array}$ & $\begin{array}{l}26.69 \\
25.48 \\
24.50\end{array}$ & $\begin{array}{l}14.84 \\
12.82 \\
17.35\end{array}$ & $\begin{array}{l}13.19 \\
11.69 \\
11.62\end{array}$ & $\begin{array}{l}3.930 \\
3.720 \\
5.950\end{array}$ & $\begin{array}{l}25.55 \\
24.61 \\
25.85\end{array}$ & $\begin{array}{l}10.58 \\
8.520 \\
14.11\end{array}$ \\
\hline Birth order & \multicolumn{2}{|c|}{ p-value $<0.001$} & \multicolumn{2}{|c|}{ p-value $<0.05$} & \multicolumn{2}{|c|}{ p-value $<0.001$} \\
\hline $\begin{array}{l}1-2 \\
3-4 \\
5 \text { or more }\end{array}$ & $\begin{array}{l}24.92 \\
25.81 \\
30.59\end{array}$ & $\begin{array}{l}12.18 \\
15.66 \\
22.23\end{array}$ & $\begin{array}{l}11.71 \\
12.85 \\
12.74\end{array}$ & $\begin{array}{l}3.530 \\
4.590 \\
6.550\end{array}$ & $\begin{array}{l}23.08 \\
27.70 \\
30.72\end{array}$ & $\begin{array}{l}8.320 \\
10.69 \\
18.77\end{array}$ \\
\hline Reading newspaper & \multicolumn{2}{|c|}{ p-value $<0.001$} & \multicolumn{2}{|c|}{ p-value $<0.10$} & \multicolumn{2}{|c|}{ p-value $<0.001$} \\
\hline $\begin{array}{l}\text { No } \\
\text { Yes }\end{array}$ & $\begin{array}{l}26.70 \\
20.34\end{array}$ & $\begin{array}{l}15.36 \\
7.280\end{array}$ & $\begin{array}{l}12.50 \\
10.08\end{array}$ & $\begin{array}{l}4.210 \\
3.530\end{array}$ & $\begin{array}{l}26.60 \\
16.94\end{array}$ & $\begin{array}{l}10.90 \\
4.870\end{array}$ \\
\hline Listening Radio & \multicolumn{2}{|c|}{ p-value $=0.2196$} & \multicolumn{2}{|c|}{ p-value $=0.8574$} & \multicolumn{2}{|c|}{ p-value $<0.1$} \\
\hline $\begin{array}{l}\text { No } \\
\text { Yes }\end{array}$ & $\begin{array}{l}25.76 \\
25.07\end{array}$ & $\begin{array}{l}14.34 \\
11.69\end{array}$ & $\begin{array}{l}12.20 \\
11.37\end{array}$ & $\begin{array}{l}4.090 \\
4.230\end{array}$ & $\begin{array}{l}23.45 \\
21.55\end{array}$ & $\begin{array}{l}10.06 \\
8.870\end{array}$ \\
\hline Watching TV & \multicolumn{2}{|c|}{ p-value $<0.001$} & \multicolumn{2}{|c|}{ p-value $<0.001$} & \multicolumn{2}{|c|}{ p-value $<0.001$} \\
\hline $\begin{array}{l}\text { No } \\
\text { Yes }\end{array}$ & $\begin{array}{l}27.41 \\
24.56\end{array}$ & $\begin{array}{l}18.27 \\
11.31\end{array}$ & $\begin{array}{l}14.46 \\
10.57\end{array}$ & $\begin{array}{l}3.860 \\
3.610\end{array}$ & $\begin{array}{l}29.72 \\
22.00\end{array}$ & $\begin{array}{l}13.52 \\
7.590\end{array}$ \\
\hline Smoke inside HH & \multicolumn{2}{|c|}{ p-value $<0.001$} & \multicolumn{2}{|c|}{ p-value $<0.01$} & \multicolumn{2}{|c|}{ p-value $<0.001$} \\
\hline $\begin{array}{l}\text { No } \\
\text { Yes }\end{array}$ & $\begin{array}{l}25.05 \\
26.21 \\
\end{array}$ & $\begin{array}{l}11.69 \\
15.99 \\
\end{array}$ & $\begin{array}{l}10.48 \\
13.43\end{array}$ & $\begin{array}{l}3.690 \\
4.440 \\
\end{array}$ & $\begin{array}{l}23.26 \\
26.52\end{array}$ & $\begin{array}{l}8.200 \\
11.35 \\
\end{array}$ \\
\hline
\end{tabular}

Table 2. Odds ratio from multinomial logistic regression analysis for the assessment of the effects of selected characteristics on nutritional status of children age under 5 years in Bangladesh, 2011.

\begin{tabular}{|c|c|c|c|c|c|c|}
\hline \multirow[t]{2}{*}{ Characteristics } & \multicolumn{2}{|c|}{$\begin{array}{llll}\text { Model-1: } & \text { Odds } & \text { Ratio } & \text { for } \\
\text { Stunting } & & & \\
\end{array}$} & \multicolumn{2}{|c|}{ Model-2: Odds Ratio for Wasting } & \multicolumn{2}{|c|}{ Model-3: Odds Ratio for Underweigh } \\
\hline & $\begin{array}{l}\text { Moderately } \\
\text { stunting } \\
\text { vs. not stunting }\end{array}$ & $\begin{array}{l}\text { Severely } \\
\text { stunting } \\
\text { vs. not stunting }\end{array}$ & $\begin{array}{l}\text { Moderately } \\
\text { wasting } \\
\text { vs. not wasting }\end{array}$ & $\begin{array}{l}\text { Severely } \\
\text { wasting } \\
\text { vs. not wasting }\end{array}$ & $\begin{array}{l}\text { Moderately } \\
\text { underweight } \\
\text { vs. not }\end{array}$ & $\begin{array}{l}\text { Severely } \\
\text { underweight } \\
\text { vs. not }\end{array}$ \\
\hline \multicolumn{7}{|l|}{ Mother's education } \\
\hline No education $^{\mathrm{a}}$ & 1.00 & 1.00 & 1.00 & 1.00 & 1.00 & 1.00 \\
\hline Primary education & 1.01 & 0.90 & 1.09 & 1.13 & $0.82^{\mathrm{d}}$ & 1.12 \\
\hline Secondary education & 0.94 & 0.84 & $0.72^{\mathrm{d}}$ & 0.92 & $0.68^{c}$ & 0.80 \\
\hline Higher education & 0.76 & 1.02 & $0.62^{\mathrm{e}}$ & 0.86 & $0.57^{\mathrm{d}}$ & 0.94 \\
\hline \multicolumn{7}{|l|}{ Father's education } \\
\hline No education $^{\mathrm{a}}$ & 1.00 & 1.00 & 1.00 & 1.00 & 1.00 & 1.00 \\
\hline Primary education & 1.04 & 1.17 & 1.14 & 0.97 & 0.96 & 1.18 \\
\hline Secondary education & $0.83^{\mathrm{c}}$ & 0.89 & 1.13 & 0.79 & 0.92 & 0.88 \\
\hline Higher education & $0.72^{\mathrm{d}}$ & $0.51^{\mathrm{c}}$ & 1.04 & 0.71 & 0.79 & $0.52^{\mathrm{d}}$ \\
\hline Other's education & & & & & & \\
\hline
\end{tabular}




\begin{tabular}{|c|c|c|c|c|c|c|}
\hline $\begin{array}{l}\text { No education }{ }^{\mathrm{a}} \\
\text { Primary education } \\
\text { Secondary education } \\
\text { Higher education }\end{array}$ & $\begin{array}{l}1.00 \\
1.13 \\
0.96 \\
0.62^{\mathrm{c}}\end{array}$ & $\begin{array}{l}1.00 \\
1.01 \\
0.75^{\mathrm{c}} \\
0.72\end{array}$ & $\begin{array}{l}1.00 \\
0.77^{\mathrm{d}} \\
0.94 \\
0.71^{\mathrm{e}}\end{array}$ & $\begin{array}{l}1.00 \\
1.03 \\
1.18 \\
1.46\end{array}$ & $\begin{array}{l}1.00 \\
0.94 \\
0.85 \\
0.70^{\mathrm{d}}\end{array}$ & $\begin{array}{l}1.00 \\
1.02 \\
0.83 \\
0.64\end{array}$ \\
\hline \multicolumn{7}{|l|}{ Region } \\
\hline $\begin{array}{l}\text { Barisal }^{\mathrm{a}} \\
\text { Chittagong } \\
\text { Dhaka } \\
\text { Khulna } \\
\text { Rajshahi } \\
\text { Rangpur } \\
\text { Sylhet }\end{array}$ & $\begin{array}{l}1.00 \\
1.01 \\
1.14 \\
0.86 \\
0.83 \\
0.97 \\
1.15\end{array}$ & $\begin{array}{l}1.00 \\
0.77^{\mathrm{c}} \\
0.74^{\mathrm{c}} \\
0.52^{\mathrm{b}} \\
0.36^{\mathrm{b}} \\
0.70^{\mathrm{c}} \\
1.09\end{array}$ & $\begin{array}{l}1.00 \\
1.07 \\
1.05 \\
0.99 \\
0.94 \\
0.78 \\
1.24\end{array}$ & $\begin{array}{l}1.00 \\
1.36 \\
1.42 \\
1.29 \\
2.02^{\mathrm{e}} \\
1.02 \\
1.45\end{array}$ & $\begin{array}{l}1.00 \\
0.98 \\
0.84 \\
0.73^{\mathrm{d}} \\
0.77^{\mathrm{e}} \\
0.70^{\mathrm{c}} \\
1.11\end{array}$ & $\begin{array}{l}1.00 \\
1.09 \\
1.05 \\
0.64^{\mathrm{d}} \\
0.99 \\
0.74^{\mathrm{e}} \\
1.60^{\mathrm{c}}\end{array}$ \\
\hline \multicolumn{7}{|l|}{ Place of residence } \\
\hline $\begin{array}{l}\text { Urban }^{\mathrm{a}} \\
\text { Rural }\end{array}$ & $\begin{array}{l}1.00 \\
0.97\end{array}$ & $\begin{array}{l}1.00 \\
0.71^{\mathrm{c}}\end{array}$ & $\begin{array}{l}1.00 \\
0.99\end{array}$ & $\begin{array}{l}1.00 \\
1.13\end{array}$ & $\begin{array}{l}1.00 \\
1.09\end{array}$ & $\begin{array}{l}1.00 \\
0.91\end{array}$ \\
\hline \multicolumn{7}{|l|}{ Sex of HH head } \\
\hline $\begin{array}{l}\text { Male }^{\mathrm{a}} \\
\text { Female }\end{array}$ & $\begin{array}{l}1.00 \\
0.94 \\
\end{array}$ & $\begin{array}{l}1.00 \\
1.03 \\
\end{array}$ & $\begin{array}{l}1.00 \\
0.97\end{array}$ & $\begin{array}{l}1.00 \\
1.18 \\
\end{array}$ & $\begin{array}{l}1.00 \\
1.08 \\
\end{array}$ & $\begin{array}{l}1.00 \\
0.89 \\
\end{array}$ \\
\hline \multicolumn{7}{|l|}{ Wealth index } \\
\hline $\begin{array}{l}\text { Poorest }^{\mathrm{a}} \\
\text { Poorer } \\
\text { Middle } \\
\text { Richer } \\
\text { Richest }\end{array}$ & $\begin{array}{l}1.00 \\
0.89 \\
0.83^{\mathrm{e}} \\
0.83 \\
0.66^{\mathrm{c}}\end{array}$ & $\begin{array}{l}1.00 \\
0.74^{\mathrm{d}} \\
0.68^{\mathrm{d}} \\
0.58^{\mathrm{c}} \\
0.35^{\mathrm{b}}\end{array}$ & $\begin{array}{l}1.00 \\
0.99 \\
1.19 \\
0.93 \\
0.87\end{array}$ & $\begin{array}{l}1.00 \\
0.92 \\
0.97 \\
0.80 \\
1.12\end{array}$ & $\begin{array}{l}1.00 \\
0.90 \\
0.76 \\
0.64 \\
0.60\end{array}$ & $\begin{array}{l}1.00 \\
0.77^{\mathrm{e}} \\
0.77 \\
0.47^{\mathrm{b}} \\
0.35^{\mathrm{b}}\end{array}$ \\
\hline \multicolumn{7}{|l|}{ Sex of children } \\
\hline $\begin{array}{l}\text { Male }^{\mathrm{a}} \\
\text { Female }\end{array}$ & $\begin{array}{l}1.00 \\
1.03\end{array}$ & $\begin{array}{l}1.00 \\
1.18^{\mathrm{e}}\end{array}$ & $\begin{array}{l}1.00 \\
0.98\end{array}$ & $\begin{array}{l}1.00 \\
0.90\end{array}$ & $\begin{array}{l}1.00 \\
1.17\end{array}$ & $\begin{array}{l}1.00 \\
1.34^{\mathrm{c}}\end{array}$ \\
\hline \multicolumn{7}{|l|}{ Mother's age at } \\
\hline $\begin{array}{l}<20 \text { years }^{\text {a }} \\
20-30 \text { years } \\
\text { More then } 30 \text { years }\end{array}$ & $\begin{array}{l}1.00 \\
0.87 \\
0.74^{\mathrm{d}} \\
\end{array}$ & $\begin{array}{l}1.00 \\
0.71^{\mathrm{c}} \\
0.74^{\mathrm{e}} \\
\end{array}$ & $\begin{array}{l}1.00 \\
0.86 \\
0.79 \\
\end{array}$ & $\begin{array}{l}1.00 \\
0.78 \\
1.03 \\
\end{array}$ & $\begin{array}{l}1.00 \\
0.82^{\mathrm{d}} \\
0.76^{\mathrm{d}}\end{array}$ & $\begin{array}{l}1.00 \\
0.64^{\mathrm{b}} \\
0.80 \\
\end{array}$ \\
\hline \multicolumn{7}{|l|}{ Birth order } \\
\hline $\begin{array}{l}1-2^{\mathrm{a}} \\
3-4 \\
5 \text { or more }\end{array}$ & $\begin{array}{l}1.00 \\
0.99 \\
1.38^{\mathrm{d}}\end{array}$ & $\begin{array}{l}1.00 \\
1.21 \\
1.62^{\mathrm{d}}\end{array}$ & $\begin{array}{l}1.00 \\
1.09 \\
0.99\end{array}$ & $\begin{array}{l}1.00 \\
1.25 \\
1.53\end{array}$ & $\begin{array}{l}1.00 \\
1.12 \\
1.21\end{array}$ & $\begin{array}{l}1.00 \\
1.22 \\
1.77^{\mathrm{d}}\end{array}$ \\
\hline \multicolumn{7}{|l|}{ Reading newspaper } \\
\hline $\begin{array}{l}\mathrm{No}^{\mathrm{a}} \\
\mathrm{Yes}\end{array}$ & $\begin{array}{l}1.00 \\
0.94 \\
\end{array}$ & $\begin{array}{l}1.00 \\
0.75^{\mathrm{e}} \\
\end{array}$ & $\begin{array}{l}1.00 \\
1.17 \\
\end{array}$ & $\begin{array}{l}1.00 \\
1.12 \\
\end{array}$ & $\begin{array}{l}1.00 \\
0.88 \\
\end{array}$ & $\begin{array}{l}1.00 \\
0.84\end{array}$ \\
\hline \multicolumn{7}{|l|}{ Listening Radio } \\
\hline $\begin{array}{l}\text { No } \\
\text { Yes }\end{array}$ & $\begin{array}{l}1.00 \\
1.05\end{array}$ & $\begin{array}{l}1.00 \\
1.03\end{array}$ & $\begin{array}{l}1.00 \\
1.01\end{array}$ & $\begin{array}{l}1.00 \\
1.09\end{array}$ & $\begin{array}{l}1.00 \\
0.93\end{array}$ & $\begin{array}{l}1.00 \\
1.07\end{array}$ \\
\hline \multicolumn{7}{|l|}{ Watching TV } \\
\hline $\begin{array}{l}\mathrm{No}^{a} \\
\text { Yes }\end{array}$ & $\begin{array}{l}1.00 \\
0.99\end{array}$ & $\begin{array}{l}1.00 \\
0.86\end{array}$ & $\begin{array}{l}1.00 \\
0.76^{\mathrm{c}}\end{array}$ & $\begin{array}{l}1.00 \\
0.82\end{array}$ & $\begin{array}{l}1.00 \\
0.90\end{array}$ & $\begin{array}{l}1.00 \\
0.79^{\mathrm{e}}\end{array}$ \\
\hline \multicolumn{7}{|l|}{ Smoke inside HH } \\
\hline $\begin{array}{l}\mathrm{No}^{a} \\
\text { Yes }\end{array}$ & $\begin{array}{l}1.00 \\
0.75\end{array}$ & $\begin{array}{l}1.00 \\
1.17^{\mathrm{e}}\end{array}$ & $\begin{array}{l}1.00 \\
1.22^{\mathrm{d}}\end{array}$ & $\begin{array}{l}1.00 \\
1.16\end{array}$ & $\begin{array}{l}1.00 \\
1.05\end{array}$ & $\begin{array}{l}1.00 \\
1.09\end{array}$ \\
\hline
\end{tabular}

\section{References}

1. Black RE, LH Allen, ZA Bhutta, et al, 2008. Maternal and Child Undernutrition: Global and Regional Exposures and Health Consequences. The Lancet 371, 243-60.

2. Alemayehu Eshetu, EskezyiawAgedew, 2016. Determinant of Severe Acute Malnutrition among Children Aged 6-59 Months in Konso, Southern Ethiopia: Case Control Study. Quality in Primary Care 24(4), 181-186.

3. Bangladesh Demographic and Health Survey (BDHS) Report, 2011. Niport, Dhaka, Bangladesh; Mitra and Associates, Dhaka, Bangladesh.

4. UNICEF, 2006. Child and Maternal Nutrition in Bangladesh.

5. Bishai D, 1996. Quality time: how parents' schooling affects child health through its interaction with childcare time in Bangladesh. Health Econ 5, 383-407.
6. White H, E Masset, 2002. Child poverty in Vietnam: using adult equivalence scales to estimate income-poverty in Vietnam. Young Lives. Working Paper No. Working Paper 6.

7. Thang NM, B Popkin, 2003. Child malnutrition in Vietnam and its transition in an era of economic growth. J Hum Nutr Diet 16, 233-44.

8. Kravdal O, 2000. A search for aggregate-level effects of education on fertility, using data from Zimbabwe, Demographic Research, 3(3), 35.

9. Kravdal O, 2002. Education and fertility in sub-Saharan Africa: individual and community effects. Demography 39(2), 233-250.

10. Kravdal O, 2004. Child mortality in India: the communitylevel effect of education. Popul Stud (Camb) 58(2), 177-92. 
11. Moursund A, O Kravdal, 2003. Individual and community effects of women's education and autonomy on contraceptive use in India. Popul Stud (Camb) 57(3), 285-301.

12. McNay K, P Arokiasamy, R Cassen. Why are uneducated women in India using contraception? A multilevel analysis. Popul Stud (Camb) 57(1), 21-40.

13. Alderman H, J Hentschel, R Sabates, 2003. With the help of one's neighbors: externalities in the production of nutrition in Peru. SocSci Med 56(10), 2019-31.

14. Das Gupta M, 1990. Death clustering, mothers' education and the determinants of child mortality in rural Punjab, India. Popul Stud (Camb) 44(3),489-505.

15. Basu AM, R Stephenson, 2005. Low levels of maternal education and the proximate determinants of childhood mortality: a little learning is not a dangerous thing. SocSci Med 60(9), 2011-23.

16. Hosmer DW, S Lemeshow, 2000. Applied Logistic Regression. Second Edition, New York: John Wiley \& Sons.

17. Christiaensen, L. and H Alderman H, 2001. Child malnutrition in Ethiopia: Can maternal knowledge augment the role of income? Washington, DC. World Bank. Africa Region Working Paper no. 22.
18. Webb P and S Block, 2004. Nutrition information and formal schooling as inputs to child nutrition. Economic Development and Cultural Change 52(4), 801-820.

19. Morales R, AM Aguilar and ACalzadilla, 2004. Geography and culture matter for malnutrition in Bolivia. Economics \& Human Biology 2(3), 373-389.

20. Medrano P, C Rodríguez and E Villa, 2008. Does mother's education matter in child's health? Evidence from South Africa. South African Journal of Economics 76(4), 612-627.

21. Francesco Burchi, 2012. Whose education affects a child's nutritional status? From parents' to household's education. Demography 27(23), 687-704.

22. Moestue $\mathrm{H}$ and S Huttly, 2008. Adult education and child nutrition: The role of family and community. Journal of Epidemiology \& Community Health 62(2), 153-159.

23. Lindelow $M, 2008$. Health as a family matter: Do intrahousehold education externalities matter for maternal and child health? Journal of Development Studies 44(4), 562-585. 
